\title{
Gender Blindness on Turkish Children's Televisions
}

\section{Zeynep Gultekin-Akcay}

Sivas Cumhuriyet University (Turkey)

The representation of the dominant gender-based discourse on television inevitably affects children's perceptions of masculinity and femininity. Gender blindness, the embodiment of gender hierarchy in which gender differences are exaggerated and attributed to natural differences between men and women, is inevitably used in the media, especially in children's broadcasting. This study aims to reveal the gender blindness in children's television on Turkey's only thematic children's television stations Minika GO and Minika Cocuk', focusing on all local productions aired in 2020. Stuart Hall's conceptualization of representation debates and text analysis expressed as constructing the meaning world of relationships and collective culture, guided the study. The representations are conveyed to the audience through the narration of the story in the animations, the plots of the story, the presentation of male and female characters, the use of space and images. In the cartoons, the frequency of female and male characters appearing on the screen, the physical appearance of the characters, their behavioral characteristics, and the spatial presentation in the stories were searched. As a result, it is possible to say that male and female characters are depicted unequally in all the themes studied in animations resulting in gender blindness.

Keywords: gender blindness, children's television, local animations, Minika GO, Minika Cocuk (Kids).

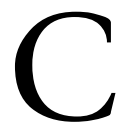

hildren's television has developed as an exclusive domain for over sixty years in the most of the Western countries (Jaggi, 2015: 123). In Turkey, the first examples of television programs for children have begun with Turkish Radio and Television (TRT) in late 1960s. As of this date, children's programs, which were found on television themselves with various contents in every period, were separated themselves as thematic television in the 1990s. Thereafter, private broadcasting has started in Turkey, both overseas and local channels were rapidly coming into the children's broadcasting sphere. 
From the moment that children's programs and television appeared in Turkey, they were broadcasting that was molded with dominant ideologies with the pre-acceptance of 'protecting children' ${ }^{1}$ Although the quantitative diversity of programs in different genres from animation to serial, news to competition has rapidly increased, paradoxically the same momentum has not been achieved in quality diversity. Programs on many channels have become increasingly similar. One of the things that make up this analogy is gender codes and related gender blindness (Livingstone, 2007). This research focuses on the representation of gender blindness in domestic children's channels in domestic animation production in Turkey. As stated by Stuart Hall (2017: 25), representation is to produce meaning for concepts through language in the mind. The representation of men and women on television constructs the meaning world of people belonging to the 'real world', relationships and collective culture. Gender blindness in children's televisions leads to the creation of common meaning maps and their internalization without being noticed. Therefore, the symbolic meanings in the television narrative are at the very center of social life (Hall, 2017: 41) and therefore it becomes a necessity to be examined. Representations are conveyed to the audience through subjects in animations, characters, and use of space and images. Based on this, the research focuses on, the axis of gender blindness, how the production of meanings are constructed in animation, such as the positioning of male and female characters in the subjects, their proportion of taking place in the image, their physical appearance, behavioral patterns, with which spaces they are identified with. All domestic production cartoons aired in 2020 from Minika Cocuk and Minika GO, the only domestic channel in the country, were analyzed accordingly.

\section{GENDER AND MEDIA}

In terms of feminist theory, gender differences in a hegemonic cultural order are biologically designated and are presented as a constant. The ulterior patriarchal ideology that steers this process is intended to make beliefs and practices that boost men's dominance over women look natural. The formative expression of French philosopher Simone de Beauvoir (1956) captures the essence of the process: One is not born, but rather becomes, a woman. Therefore, gender is not something that is originally present in people. On the contrary, it is a set of understanding created by behaviors and social relations in day-to-day practices. According to feminist theoreticians who argue that family, school, and parliament play a major role in building a gender, media sometimes plays a larger role than these structures.

1 Children's material will either be in coded form, or it will take the form of education, designed to deter and protect the young from risk-taking behavior: for example, storylines in children's soap —Grange Hill, Byker Grove - (Messenger-Davies, 2008: 92). 
The complex relationships between gender representation and media have been the focus of much academic debate, in general, feminist critics presumed that the media not only reflect social values but also play a major role in their dissemination (Byerly and Ross, 2006: 2). Feminist media scholars have been criticized the media for their role in legitimizing and reinforcing gender-related stereotypes, and in doing so, for their contribution to the continuation of gender blindness. In the media, gender representations have been characterized by either blindness or hostility to feminine identities and lifestyles. It should also be noted that most of the media content traveling the world is still quite gender blindness. It will also be useful to address gender blindness at this point. According to Kathryn Scantlebury (1995: 136), gender-blindness is grounded in the Plato's idea that sex is the differences that make no differences. Genderblindness debates specify, gender differences are overstated in media, politics, and research, and that emphasizing differences between men and women reifies the gender hierarchy by attributing gender inequality to fundamental, natural differences between men and women. According to a view, gender-blindness is a strategy used to reinforce internalized behavior and sharpen gender differences. Notably, gender-blindness does not advocate for being 'completely blind' to gender; serves to reduce one's focus on differences (Martin and Phillips, 2017: 29). United Nations Educational, Scientific and Cultural Organization's (2019:4) definition for gender-blindness is quite striking:

Gender blindness is the failure to recognize that the roles and responsibilities of men/boys and women/girls are given to them in specific social, cultural, economic, and political contexts and backgrounds. Projects, programs, policies, and attitudes that are gender-blind do not take into account these different roles and their diverse needs. They maintain the status quo and will not help transform the unequal structure of gender relations.

One of the primary critiques of media's gender blindness argues that the historical construction of femininity and masculinity has been conducted through binary as well as hierarchical oppositions. While generally men have been presented as normal, representing the majority of society, women have been presented as the minority 'other', the 'second sex' - the exception, the incomplete, the damaged, the marginal, and sometimes even the bizarre. By this perspective, men and women have been constructed, systematically, as inhabiting opposing sides of these dualities, with the masculine associated with the highly valued rational-spirit-culture-public-subject-West-modern and the feminine with the devaluated emotional-body-nature-private-object-east-traditional. Furthermore, the personality traits of women are depicted as being fundamentally different in nature from those of men. The male subordination of women is presented as related to their sexual drive. In contrast to the emphasis on women's appearance, men are defined by action: women 'appear' and men 'do' (Lemish, 2010: 10-12). Gender in many areas of social life gender blindness, which can also be defined as failure to be noticed, is an important problem that we encounter on children's televisions. Scholars in children's television argued the different forms of gender blindness encountered and the reasons for this. 


\section{CHILDREN, TELEVISION AND GENDER REPRESENTATION}

The early research on gender stereotyping and blindness on children's television arose out of the heightened gender consciousness generated by the second wave of the feminist movement. These studies found that many cartoons had only male characters and in case females that appeared, they needed to be rescued. Overall, female characters were portrayed as less important and less responsible than males. The male characters were portrayed in a greater variety of roles and occupations, whereas female characters were portrayed as housewives, mothers, girlfriends, grandmothers, maids, nannies, nurses, teachers, secretaries, waitresses, or witches (Thompson and Scantin, 2007: 140). After the early studies, recent researches concluded that though stereotyped portrayals of gender were still prominent in children's cartoons, some significant changes had occurred in two decades. There were pieces of evidences of female leaders who were now shown to be more independent, assertive, responsible, intelligent, competent, and helpful. In the 1990s and 2000s, female cartoon characters were outnumbered by male characters by four or five to one. In this term, in children's television, adult minority females are invisible and those younger minority females, when included, are presented as background characters or fillers (Jaggi, 2015: 125).

Looking at the presentation of gender blindness, on the children's programs, there is clear gender blindness all over the world, in public and private television, in international and domestic programs, in animated and real-life formats. In connection with gender blindness, researches show that main characters are generally males, and males are represented twice as females. Female characters are underrepresented as animals, monsters, robots, and other fictional beings. This is particularly astonishing since in such cases the biological sex of a character is purely constructed. Yet it can be discerned that the protagonists of children's television are much more frequently constructed as male than female (Götz et al., 2008: 4-6). Another point is on children's television and gender-blindness, non-gendered imaginary characters are considered 'naturally' to be male unless they are specifically marked as female through a process of sexualizing their appearance. It should not be forgotten that on these programs, certain symbols are gendered and reinforced by market forces as 'girlish' (Lemish, 2014: 180). Moreover, like 'adult women', 'girls' are characterized as passive, emotional, caregiving, childish, sexy, subordinate to males, and of lower social status. Such dominant media messages in texts designed for children continue to promote the same restrictive ideologies of femininity and masculinity that characterize media in general and say little about the multifaceted aspects of girls and boy's capabilities, and potential contributions to society (Jaggi, 2015: 124). Besides, Lemish (2010: 16) stated that media superheroes, who were being popular throughout the world, play a primary gender role - like girls - in the development of male identity. They were the embodiment of the 'perfect' traditional man: most heroes were strong, brave, muscular, always on the lookout to defend the weak, undefeatable, active in the outdoors, full of adventure, and are adored by females. In addition to the 
above, it is worth mentioning that superheroes represent gender stereotypes: Historically, most superhero characters were male and were defined by their muscularity and strength, as well as their keen minds and problem - solving abilities, and being the leader of a team (or acting alone) more often than female superheroes. In contrast, female heroes have been defined by their passivity: innocent and selfless in situations of forced submission whether through physical confinement, muteness, or death. Female superheroes are expected to be more likely to ask questions, ask for advice, and praise others, while male superheroes are expected to interrupt more, laugh more at others, brag, order or boss others, insult, threaten, and show more anger (Baker and Raney, 2007: 28). Collectively, the overwhelming message they convey has being that 'toughness' is the most valued masculine quality in need of cultivation. This 'tough guise' can be viewed as the male equivalent to the female 'beauty myth' -as both offer very restrictive social scripts and visions for what it means to be a woman and a man in our times (Lemish, 2010: 16).

\section{Children, Television and Gender in Turkey}

In Turkey, the first examples of television programs for children have begun with TRT the late 1960s. The first program for children was the Bulgarian cartoon Margaritkata (1965-Todor Dinov) in 1968. As of this date, children's programs found on television themselves with various contents in every period. In the early 1970s, an important step was taken for children on television: Animation companies in the field of advertising started to produce programs for TRT. These companies saw cartoons as a medium for the consumption economy; they created content — themed 'children enjoying life' (Cankaya, 2003: 127). Having a shortage of domestic content, TRT also did not neglected to broadcast foreign programs like Candy, Heidi, etc. (BEBKA, 2018: 13). In the '90s, satellite broadcasts and foreign children's channels started to be watched, private channels were started airing, and also TRT withdrew local children's programs' support. In these circumstances, foreign cartoons became identical to children's programs (Abal1, 2012: 147). In the meantime, in the domestic programs, family, marriage, motherhood was emphasized. The early 2000s, 30 thematic children's channels started airing. Of these, 11 were domestic channels and the rest were foreign channels. Almost all domestic channels, except TRT Kids, preferred Hollywood-based children's programs due to their low cost (Abalı, 2012: 106).

Almost all domestic channels broadcast adopted the conservative approach of childhood (child is 'Tabula Rasa', everything should be filtered according to the desire of the adult) in their content (Timisi, 2011). Moreover, these channels generally played role in construct nationalist conservative content by the socio-political conditions of the period. There was an astonishing example of this: Yumurcak TV (2007-2016). The channel that is now accepted as a terrorist organization, had included anti-Semitic, anti-Western, constructed gender content in its broadcasts. In sum, it is possible to say that children's programs in Turkey repeatedly were molded with dominant ideologies with the 
pre-acceptance of 'protecting children'. Although the quantitative diversity of programs in different genres from animation to serial, news to competition has rapidly increased, paradoxically the same momentum has not been achieved in quality diversity. Programs on many channels have become increasingly similar. One of the things that make up this analogy is gender codes and related gender blindness. And it is worth underlining that most particularly, in domestic productions, gender codes, have begun to be represented on the axis of tradition, religion, and the state.

\section{METHODOLOGY}

Media texts can be analyzed to deconstruct gender representations in different ways. One of them is textual analysis. Textual analysis is an attempt to gather information about sense-making practices. Further, it can allow us to better understand the sense-making media culture in which we live by seeing its limitation, and possible alternative to it (McKee, 2003: 14). The polysemous nature of media texts can create multiple levels of meaning hence textual interpretation is a serious process (Jaggi, 2015: 125). This paper used textual analysis to reveal how gender blindness is represented on private children's televisions. The main purpose of this study is to search how gender blindness is shaped on children's televisions. Answers are sought for the following questions within the framework of the study's main purpose: How is the gender blindness representation made to seem natural? For gender blindness, what is foregrounded and what is backgrounded, and are there any notable absences? How are women and men stereotyped in characters? How are characters physically portrayed in creating gender codes? What are the behaviors of characters like in representing gender codes? How are creatures portrayed in representing gender codes? What are the spatial states of characters like in representing gender codes?

Turkey has a total of eighteen children's channels that broadcast now. Of these, fifteen are international and three are national companies (RTSC, 2016). One of the national channels is a public broadcaster: TRT, the other two are private channels: Minika Go and Minika Çocuk. Minika Go started air in 2011 and Minika Çocuk in 2012. These channels belong to the Turkuvaz media group, also known for their closeness to the government. Both of these media groups broadcast with a conservative mind of childhood and they also present conservative discourse (religious, nationalist, patriarchal, etc.) of the government. These contents are in domestic productions. The domestic animations of the two channels are only 7 out of 65 animations in total. These domestic 7 animations, bearing traces of the country's dominant social structure as well as the ideology of the government, were studied to get a sense of how gender blindness works. I studied all (15) episodes in 2020 broadcasting period to get a sense of how to represent gender blindness, and what various aspects of its meaning. The research looked at each program one by one. The textual analysis of different episodes of every program was accomplished in conjunction with each other. To analyze the meanings related to gender blindness, the male and female characters in the narrative were 
analyzed according to their physical characteristics, dressing, social relations

(react each other, move, speak, etc.), take control of the narrative and spatial positioning, whose voice is heard. Chart 1 gives a list of the shows included in the study.

Chart 1. List of the shows used in the study

\begin{tabular}{|c|c|c|c|c|}
\hline $\begin{array}{l}\text { Name of the Television } \\
\text { Show }\end{array}$ & $\begin{array}{l}\text { Name of } \\
\text { channel }\end{array}$ & $\begin{array}{l}\text { Name of Producer and } \\
\text { Director }\end{array}$ & $\begin{array}{l}\text { Year of the } \\
\text { production }\end{array}$ & $\begin{array}{l}\text { Date of } \\
\text { broadcast } \\
\text { on television }\end{array}$ \\
\hline $\begin{array}{l}\text { Altın Öğütler (Pearl of } \\
\text { Wisdoms) }\end{array}$ & Minika Go & $\begin{array}{l}\text { Producer: } 2 \mathrm{G} 1 \mathrm{C} \\
\text { Director: Ümit Özkan }\end{array}$ & 2016 & 2016 \\
\hline $\begin{array}{l}\text { İstanbul Muhafızları } \\
\text { (Istanbul Guards) }\end{array}$ & Minika Go & $\begin{array}{l}\text { Producer: Neher Productions } \\
\text { Director: Musab Gündüz and } \\
\text { Ammar Gündüz }\end{array}$ & 2016 & 2016 \\
\hline Hızlı Ayaklar (Quick Feet) & Minika Go & $\begin{array}{l}\text { Producer: Neher Productions } \\
\text { Director: Musab Gündüz and } \\
\text { Ammar Gündüz }\end{array}$ & 2019 & 2019 \\
\hline Alpman & Minika Go & $\begin{array}{l}\text { Producer: Miner Productions } \\
\text { Director: Osman Şentatoğlu }\end{array}$ & 2018 & 2018 \\
\hline $\begin{array}{l}\text { Maceracı Yüzgeçler } \\
\text { (Adventurous Fins) }\end{array}$ & $\begin{array}{l}\text { Minika } \\
\text { Çocuk }\end{array}$ & $\begin{array}{l}\text { Producer: Imaginite } \\
\text { Productions } \\
\text { Director: Fatma Yıldırım and } \\
\text { Erhan Korkmaz }\end{array}$ & 2017 & 2017 \\
\hline $\begin{array}{l}\text { Neşeli Dünyam (My } \\
\text { Merry World) }\end{array}$ & $\begin{array}{l}\text { Minika } \\
\text { Çocuk }\end{array}$ & $\begin{array}{l}\text { Producer: Animascope } \\
\text { Productions } \\
\text { Director: Ozan Kaygısız }\end{array}$ & 2017 & 2017 \\
\hline $\begin{array}{l}\text { Homur ve Gumur } \\
\text { (Dumper and Skoop) }\end{array}$ & $\begin{array}{l}\text { Minika } \\
\text { Çocuk }\end{array}$ & $\begin{array}{l}\text { Producer: Mavi Baykuş } \\
\text { Studios } \\
\text { Director: Serhat Albamya and } \\
\text { Ethem İbrahim }\end{array}$ & 2017 & 2017 \\
\hline
\end{tabular}

Source: Own elaboration.

Before the findings, briefly explaining the theme of the shows facilitates the understanding of the analysis.

Altın Ögütler (Pearl of Wisdoms): Cartoon tells the hadiths of Prophet Muhammad. There is no dialogue in the cartoon. The cartoon is black and white. Hadiths were represented by family (mother, father, kid, grandfather) living in Istanbul.

Ístanbul Muhafizları (Istanbul Guards): The cartoon tells the struggles of Mehmet and friends (Ali, Zeynep, Elif), who live in small neighborhoods in Istanbul, against the villain named Gurgen and Azmi who try to destroy the historical places of Istanbul. A 300-year-old plane tree helps children in this struggle. 
Hizlı Ayaklar (Quick Feet): In the cartoon, the adventures of Ali, a boarding student at Koca Yusuf at Sports High School in Ankara, and his fellow athletes are told.

Alpman: Cartoon tells, the lives of Turks living in Central Asia before the Ottoman in the 6th century. The adventures of Alpman, the son of the Khan of Kartal Obası, one of these nomadic communities, and his friends (Oguzhan, Baybars, Kaçgar, Melike, Ece) are told.

Maceracı Yüzgeçler (Adventurous Fins): The cartoon tells the adventures of Biba, a 9-year-old red mullet living in the waters of the Bosphorus, and his friends who are fish. There is also a mermaid Alesta who helps children with their lives.

Neşeli Dünyam (My Merry World): One day, Nese and her younger brother Mutlu meet their new friends Mini and Mani who have lived Pink Planet and have landed on earth because their spacecraft broke down. Neşe tries to prevent space creatures (Sapalat) from attacking the world. Her biggest helpers in this regard are Mani, Mini and her family (mother, father, brother Mutlu).

Homur ve Gumur (Dumper and Skoop): The cartoon tells, the story of toy truck (Homur), dozer (Gumur), cars (Vızır, Inga), helicopter (Patekar), wind-up mice (Mingir, Tingir) toys living in a house.

\section{FINDINGS}

During the analysis of text, the sense-making practices that were in place in a culture where it is circulated as meaningful were found. Domestic cartoons make sense of gender blindness via stereotyped portrayals of gender. Therefore, the study seeks to find out, how female and male characters of shows are represented, whose voice is heard, how creatures is represented, how characters are dressed (color, make-up, accessory choice, etc.), how characters are behaved, and where characters are spatially represented.

\section{Female and Male Characters on Cartoons: Who is the Main Protagonist? Whose Voice is Heard?}

The unequal gender distribution of the characters stands out in the cartoons. It is possible to catch the first clue of this inequality by looking at the main protagonist: of all the animations, only the My Merry World has a female main character. Moreover, there is a dearth of female characters across the shows. Although the male protagonist's core group of friends generally consists of male members, the functional role of female characters is limited to being a part of their daily escapades. In the Pearl of Wisdom, father, child, grandfather, neighbor, teacher, grocer, greengrocer is all male and it is very difficult to see female characters. Or in Adventurous Fins, Mermaid Alesta only appears in difficult times. The unequal representation of males and females is not only for human characters, but for also creatures. The Fish in Adventurous Fins, the robot and the alien in My Merry World, the car on Dumper and Skoop, and the tree in Istanbul Guards are male. 
Names, vocalization, and form of address are signs that signify that the creative characters are male. Mehmet, the name of the main protagonist of the Istanbul Guards, can easily be understood as masculine both in Turkey and throughout the Islamic world, as this name is one of the prophet's names. When we look at the name of the main character of Quick Feet, we can see traces of similar masculinity. The name Ali is also used for the caliph both in Turkey and in Islamic geography. In almost all cartoons, male characters are vocalized deep and bass, while female characters are vocalized thin and high-pitched. In fact, this high-pitched voiceover is emphasized enough to disturb the audience in My Merry World, Dough, and Gumur and Adventurous Fins, as if the speeches of the female characters are like screams. In the cartoon Dumper and Skoop, one of the male characters even said to the female character 'What kind of sound is this! It pierces one's ear'. Gender inequality can also be kept up within the forms of addressing the characters. Words of affection vary according to the gender of both the children and the addressee. While female characters speak with affectionate words (my beautiful, sweetheart, dear, etc.), the way the male characters address varies according to gender. As an example of this discourse of female characters, in Alpman. Alpman's mother calling children my sweeties and in my Merry World, Neşe's mother calling 'Neşe my dear', can be given as an example. Whereas, male characters are addressed like 'well done you little scallywag', 'fo shizzle my nizzle'. These reveal the gender differences in the characters' voices. Usually, a story is told through songs. In these songs where the aforementioned narration is adopted, one hears once again male voices. Sometimes the story is told with a narrator. These narrators are sometimes a male plane tree, a male storyteller, an old male fish.

\section{Gender Blindness in Physical Qualities of Characters}

Producers of children's shows around the globe choose to express gender blindness in the physical and behavioral qualities of characters and their spatial presence and thus attract viewers. The physical characteristics, clothes, and colors of the characters in the programs are very convenient to analyze in the context of gender blindness as they give an idea about the culture we live in.

In the text analysis, the codes such as being well-groomed, physical appearance, make-up, and hair of the characters were analyzed. It was observed that well-groomed characters are portrayed by women. In the cartoon My Merry World, two girls and the mother look fit while the father looks fat, bearded, and with messy hair. In Homur ve Gumur, mice are men, with one being short and the other one being tall and even fat. In another cartoon called Adventurous Fins, a school bus driver and a doctor are portrayed in sloppy clothes, with poorlygroomed hair and a belly. This manifests itself in Gurgen's bald head and Azmi's dowdy clothes in the cartoon Istanbul Guards. In other cartoons such as Alpman, female characters look physically thin while the way men look varies. Women are portrayed as thin and tall in cartoons, which do not match the physical characteristics of Turkish women, whereas it is suitable for the narrative of the global children's broadcast. In this sense, men are portrayed in a way similar to their social characteristics and global characters, and this is comprehensively 
set forth in Götz and Lemish's (2012: 20) study over various global shows. Male characters represent a highly masculine physique. They are shown tall, strapper but not muscular. While this representation tells the audience that men should be huge than women, it also presents the physical structure of Turkish men to the audience. Male characters such as Baybars, Mr. Tuğrul in Alpman, Buba, Hamsi in Adventurous Fins, Dad in Pearl of Wisdom are taller and larger than female characters, but they do not have an athletic body.

Gender blindness is sometimes reproduced by the de-sexization of physical qualities. The cartoon Quick Feet is an example that this is best observed. All the characters in Quick Feet have the same height and weight. The de-sexization of female characters also builds blindness in a way. When it comes to nonhuman characters, no particular physical quality is portrayed by men while it is the opposite for women. In Homur ve Gumur, the character named Vizir is a race car wearing makeup to emphasize its slanted and seductive eyes as the gender identity is narrated in a polished manner. However, there is no symbol for the truck named Hamur. The makeup and hair of the fish Alesta, another non-human character, and its friends are strikingly emphasized while the same effort is not apparent for the male characters of Adventurous Fins.

\section{Clothes and Colors in Creation of Gender Blindness}

Sexist use of colors and preferred clothes in daily life are important in building children's perception of gender. The moment you wrap a baby girl in a pink blanket and a baby boy in a blue one, building gender-based roles is initiated. One can argue that such preferences are created by design in children's shows and that is the case in the movies analyzed. In almost all shows analyzed, female characters are dressed in pink and its shades while male characters are dressed in blue and dark colors. The race car Vizır in Homur ve Gumur, alien Mini's hair in My Merry World, the clothes of mermaid Alesta in Adventurous Fins, the trousers of Zeynep in Quick Feet, clothes of Elif in Istanbul Guards, and colors of clothes of Melike and Gulsah on Alpman are in red, pink and purple shades. The sexist use of colors is not only presented in clothes, but also in describing spaces. Representing the private space, the house is often presented in light colors and even shades of pink. In Istanbul Guards, it is possible to encounter pink, purple, and yellow colors in many of the old wooden houses with bay windows. In Adventurous Fins, the colors of the houses made of seashells are red, purple, and pink. In Alpman, the colors of the tents, which are the home of the nomadic society, are light tones of cream color. In My Merry World, the homes of aliens Mani and Mini are also pink, and even their rooms where they observe the world are shaded red. Looking at the use of colors on men, the notion of "man does not wear pink" common in Turkish society is felt in the presentation of male characters in cartoons (according to the common sense in society, a man who wears pink becomes feminine, and a man who becomes feminine is either weak or gay!). In male characters, the use of pink, purple or red is never encountered. Because a man is a 'real man!' and does not wear pink! The colors used for the main characters in the Istanbul Guard are blue, green, brown, and black. The clothes of all athletes and trainers in Quick Feet are 
also blue and black. It is possible to talk about the same representing in Alpman, My Merry World and Adventurous Fins. Although Pearl of Wisdom was produced in black and white, what is quite striking is that sexist color codes are also used here. While black or gray tones are generally used in men's clothing, white is used in the female character.

In addition, female characters are usually portrayed in a skirt or dress. Wearing a skirt or a dress is absolute for adult women. In all analyzed cartoons, adult women such as mother, teacher, grandmother, neighbor woman wear either skirt or dress. While some of the female children wear skirts/ dresses, others are presented with long trousers or tights. While Zeynep wears a skirt in the Istanbul Guards, Elif wears overalls. In Quick Feet, all of the female athletes wear long tights. In Alpman, Ece wears a traditional trident-skirt while Melike wears a purple shalwar. In Adventurous Fins, all members of the orchestra wore dresses. Zuzu also wore a yellow dress in My Merry World. The portrayal of a female in a skirt or a dress reminds of how women are confined to wearing a skirt or a dress. Adult or children, no female characters are presented with shorts or miniskirts. What is striking in men's clothes is that they only wear trousers and sweatpants. Just like the female, male characters never wear clothes such as shorts or bermuda.

Accessories are particularly used to consolidate sexism. Accessories such as hair clips, headbands, necklaces, fancy hats, wristlets, belts, and bags are an integral part of female characters in almost all shows. In the Istanbul Guards, Zeynep has a red hairpin and Elif has a blue hairpin. In Quick Feet, there are Hatice's earrings and Bahar's badge. In Alpman, mother has an embroidered headdress and a necklace of Melike. In Adventurous Fins, Alesta has a yellow buckle and a necklace with shiny stones. Zuzu wears sunglasses in My Merry World. In Dumper and Skoop, Vizır has colored hairpins. In order to regulate the social relations between men and women among Muslims, women should wear headscarves. When a woman goes out in the public sphere, she should be covered. This perspective also reproduces the patriarchal social structure. Many adult women wore headscarves in Pearl of Wisdom, Istanbul Guards, Alpman, Adventurous Fins. In the presentation of the adult woman in the public sphere, this detail is not omitted and masculine domination is built.

Looking at men, most of them wear glasses and hats as accessories. In Anatolia, it is believed that men should grow a mustache in order to have a say. If the man does not have a mustache yet, his words are not listened to and taken seriously, because he 'should not be Derogatory!' like a woman. In cartoons, many adult men with mustaches and beards are used to represent that men are strong and mature. Examples of those cited are a man who says 'My mustache is my honor, I cannot give up on them' in Alpman, or the old man who says 'I am an old man and I can't be beardless' in Adventurous Fins.

\section{Behavioral Characteristics of Characters: Men Do it, Women WATCH!}

Thompson and Zerbinos (1995: 668) reported that children perceived male characters as active and female characters as rather meek, domestic, interested in 
men. One can argue that such perception is portrayed in a way to sustain it in the cartoons analyzed based on writers. It is portrayed that while outdoor motionbased and individual activities are usually performed by male characters, female characters are portrayed in activities performed by groups. In Pearl of Wisdom, while the father can solve the problem with his neighbor himself, the mother can solve the problem with her neighbor by getting help from her husband. In the Istanbul Guards, the main character Mehmet does not allow Gürgen to destroy the Tekfur Palace. But first, he gets an idea from Ali, Zeynep, and Elif. However, it makes the final decision and plans and implements it independently of the recommendations. Again in this cartoon, Elif and Zeynep need Mehmet to get rid of the second trap even if they escaped from traps. In Alpman, Baybars, Ece, Kaçgar, and Alpan make plans for the person who stole their horses. For the plan to be successful, Alpman must shoot arrows and overcome the bad guys. In Adventurous Fins, the main male character Biba takes the lost baby fish to its mother. In My Merry World, the male creature Mani, prevents the evil alien creatures from attacking the world. In Dumper and Skoop, instead of moving the machine together, Gumur does it alone. The portrayal of female characters is overshadowed by the portrayal of men in shows. Opportunities to stand out, be followed, and be in the limelight seem to be usually provided to men.

Male characters are the ones to give advice, make recommendations and make the final decision. Men are portrayed to guide a process and a community in many actions such as the father of My Merry World offering recommendations about what children should do at home after the mother leaves. The plane tree in the Istanbul Guard stops the children, who are angry with Gürgen, by giving them advice. In Quick Feet, children who do not comply with the coach's recommendations (going to bed early, eating regularly and exercising, etc.) are defeated in the competitions. Angered by this defeat, the trainer said the last word by punishing the children. In Alpman, wise Kadir is consulted to find the missing girl. Kadir is a wise person, his words are like sacred knowledge, reliable, and what he says becomes true and always justified. In Adventurous Fins, instead of the Alesta (adult female), Biba takes the genius friend Çupa's suggestions seriously. In Dumper and Skoop, Gumur does not accept whatever Vizir (female) says and wants his own words to be accepted.

Male characters have a second chance if they make mistakes, but female characters are only given one chance. It is a male who sees the mistakes of female characters who do not use this chance well, takes lessons, and reaches the conclusion. In Dumper and Skoop, the dialogue between the toy cars that will take the exam is a good example of this situation. Gumur says 'I never make mistakes so I don't need an eraser!' and then makes a mistake in the exam. However, he is given an eraser by his friends and he gets a second chance. In Alpman, Ece talks to the robbers, gets trapped, and waits to be rescued. However, Baybars talks to the robbers, gets trapped but manages to escape from the trap. He even saves Ece from the trap.

If male characters cannot solve the problem, they ask for help from an adult male instead of asking a woman. When children playing games in Pearl of Wisdom cannot get along with each other, they seek help from the local grocery 
Uncle Ahmet instead of consulting their mothers nearby. In Istanbul Guards, Azmi, who needs to learn the location of Adile Sultan Pavilion, does not trust his teacher's answer and asks his friend Gürgen. In Quick Feet, Ali listens to his boyfriends competing in other branches instead of listening to the suggestions of his girlfriends in the same branch. Because, according to Ali, although he is in the same branch as girls, they will not be able to give him the information that needs because the physical characteristics of the girls are weak. In Alpman, when Alpman and his friend Baybars cannot find the bay horses, they consult the wise Kadir instead of asking his mother, who takes care of the horses and knows where they are.

Another characteristic of male characters brought to the forefront is being sophisticated. As a part of their speech, men give information through lots of explanations, make definitions and even use terminology from time to time and refer to scientific information. If there is a male character in a scene, he is the one to give information. In My Merry World, younger brother Mutlu is an inventor. Describes his new invention to fight evil 'This icematic working with electromagnetic waves will definitely defeat the villains!'. Even if Neşe fails to invent this tool, she will use it. In Dumper and Skoop, the smart mouse Tingir plots for a cheese machine. For this, he designs a lever and a pulley system. He uses trigonometric angles etc. while explaining his plans to his friend Mingir uses scientific language. Another point is that almost all characters that solve problems are men. Problem-solving is described as being aware of one, taking an action or saying something about how to solve it, and finally solving it. Problem-solving characters are described by Götz, Neubauer, and Winter (2012: 114) as do-it characters. Do-it-characters focus on actions. What matters to them is to get things done. In the cartoons analyzed, male characters largely stand out for their problem-solving skills. The fact that problem -solving is a feature that requires reasoning and women are not included in it, underlines the predisposition of women to emotions. Female characters are portrayed in association with emotions such as excitement, fear, astonishment, anger, and worry. In Alpman, Alpman calms Melike, who is worried about immigration. In Adventurous Fins, Biba helps Tuti who loses her homework. Ali consoles Bahar, who lost the game in Quick Feet. Women are necessarily soothed by men who use their minds because of their excessive sensuality in stories!

\section{A CLICHÉ: WOMEN AT HOME, MEN OUTSIDE}

Where the characters are incorporated into the story is a way to position them in gender-based roles. The environment in which the character is frequently encountered is part of positioning the character implicitly/explicitly. One of the points where gender blindness is observed is the positioning of the characters in public and private spaces. Indoor, school, street/neighborhood, nature/garden, workplace/office are the places used in the movies analyzed. While women are seen in neighborhoods/streets or nature/courtyards as a part of public life, they are usually portrayed in a private space. In Dumper and Skoop, while toys are 
playing in the garden, Vizır is at home and watches them. At Pearl of Wisdom, the mother is only shown in the kitchen. In the Istanbul Guards, the only place we see a female teacher is inside the classroom. In Alpman, adult women are only in the tent. In Adventurous Fins, Alesta are represented at house parties. In My Merry World, mom is either in the kitchen or in the garden of the house. The place where male and female characters are seen together in the house is either the living room or the kitchen. Male and female characters are never shown together in places other than this.

\section{DISCUSSION AND CONCLUSION}

In domestic cartoons, the performance and perpetuation of gender-based roles keeps handing down the patriarchal ideology. It is possible to see this situation in the physical, behavioral and spatial representations of the characters. Most of the programming narratives are male-centered. Generally, the main protagonist of cartoons is men. Females in the analyzed text operated in groups while males are more active as loners. The representation of female in creatures is also less. Masculine voiceovers and nomenclatures are used for the gender representation of the creatures. Moreover, there is gender discrimination in the way characters speak to each other. The stereotype that women are emotional and sensitive is felt in these speaking. The soundtracks and voices used for the storytelling are also male. In this case, the answer to the question of who appears in domestic cartoons and whose voice is heard is obvious: male! The male and female dichotomy is also used for characters' appearances. The costumes, accessories, colors used are images that reinforce this distinction. While the physical representation of the female characters coincides with the global children's programming, the physical representation of the male, on the contrary, corresponds to the Turkish representation. The fact that Turkish men take care of themselves and be fit evokes Queerness in social memory. Queerness is defined as deviance both for power and in culture. It was previously mentioned that the broadcasting policy of the channel is compatible with the ideology of the government. This ideological acceptance of the broadcasting institution is commonplace for the neglected representation of the physical appearance of males in cartoons.

The use of attractive, well-groomed, make-up characters for female representation is a reflection of this hegemonic understanding of sexism. Likewise, the 'color stereotype' is built as an indispensable element for all films. Female characters are portrayed in costumes of red and pink shades no matter how old they are or what their profession and position is while males are presented in blue and its shades in another aspect of the stereotype. The stereotype of pink for females and blue for males are consolidated in movies. Besides, there is an emphasis on the fact that a male dressed in colorful tones may be gay. This emphasis both points to intolerance to homosexuality and also marginalizes it. Gender discrimination is represented in the dressing of female characters. Behind the persistent emphasis of this discrimination, there is the ideology of the power that has a religiously conservative ideology adopted by the 
channel. An example of scenes where this appears is when none of the female characters wear short shorts, dresses, or skirts. Moreover, the representation of almost every adult woman with the headscarf exemplifies this. At this point, the emphasis of the government that women who do not wear headscarves should be punished is presented in the background. While the male alone is represented in the public sphere, the female is represented in the public sphere by the group. The place where the female is presented alone is only a private space. Unfortunately, the proverb "the wife has one mind, the man has nine minds", which reveals the gender perception of the country's culture, is also present in the cartoons. It becomes a male who makes the final decision. The female should definitely consult the male at the decision stage. There is also a sexist stereotype in the division of labor for males and females. The woman looks after the child at home, cooks, and the man makes money. What is even more striking is the representations of grandparents.

As a result, there is gender blindness in cartoons, and this situation is further deepened by the ideologies of the power that the channel adopts. These programs are productions in which the world of children and their values are not taken into account. Because the world of children is an inclusive and pluralistic world without sharp distinctions. In Turkey, it will be beneficial to increase the number of scientific researches and collaborate with the producers and scientists in order to protect the values of children and increase gender awareness.

Zeynep Gultekin-Akcay (zga@cumhuriyet. edu.tr), received $\mathrm{PhD}$ from Ankara Gazi University, department of journalism, has been working at Sivas Cumhuriyet University since 2014. She is the author of the book titled, Ideology and Communication Symbolic Reflections of Intellectual Designs (2020, Peter Lang Publication). And also she has book chapters. One of the more recent is: The Adventures of Snow White in Turkish Cinema (eds. Chris Pallant and Christopher Holiday, Snow White and the Seven Dwarfs New
Perspectives on Production, Reception, Legacy- Bloomsbury Publication, 2021). Some of her recent articles are: Hybridized Children's Plays through Screens (2018), Three Forms of the (Fair Tale of) Snow White and the Seven Dwarfs: Brothers Grimm, Walt Disney and Ertem Göreç (2020). She is interested in children and media, television studies, gender and media issues. She lectures the courses on communication studies, current issues of the media, oral history and media at Radio Television and Cinema department.

\section{References}

Abalı, Nesibe (2012). "Türkiye'de Animasyonun Dünü ve Bugünü" [Past and Present of Animation in Turkey]. Bilişsim, 147, pp. 106-114.
Albamya,SerhatandEthem,İbrahim(2017). Homur ve Gumur [Dumper and Skoop]. Available at: <http://www.minikacocuk.com.tr/ 
72 programlar/homur-ve-gumur>. Accessed 15 August 2020.

Baker, Kaysee and Raney, Arthur A. (2007). "Equally Super?: Gender Role Stereotyping of Superheroes in Children's Animated Programs". Mass Communication and Society, 10(1), pp. 25-41. DOI: $<10.1080 / 15205430709337003>$.

Beauvoir, Simone de (1956). The Second Sex ( $2^{\text {nd }}$ ed.). (H. Parshley, Ed.). London: Love and Brydone Printers.

Bursa, Eskişehir, Bilecik Kalkınma Ajansı BEBKA (2018). Animasyon Sektörü Raporu [Animation Industry Report]. Eskişehir: BEBKA.

Byerly, Carolyn and Ross, Karen (2006) Women and Media a Critical Introduction. Oxford: Blackwell Publishing.

Cankaya, Özden (2003). Bir Kitle İletissim Kurumunun Tarihi TRT: 1927-2000 [The History of Mass Media Institution TRT: 1927-2000]. İstanbul: YKY.

Dinov, Todor (1965). Margaritkata. Available at: <http://youtube.com/watch?v=1hMkh v5NLzo>. Accessed 28 April 2021.

Götz, Maya and Lemish, Dafna (2012). Sexy Girls, Heroes and Funny Losers Gender Representations in Children's TV Around the World. Frankfurt: Peter Lang. <http://doi. org/10.3726/978-3-653-01426-6>.

Götz, Maya; Neubauer, Gunter, and Winter, Reinhard (2012). "Heroes, Planner and Funny Losers: Masculinities Represented in Male Characters in Children's TV". In: Götz, Maya and Lemish, Dafna (ed.). Sexy Girls, Heroes and Funny Gender Representation in Children's TV Around the World. Frankfurt: Peter Lang, pp. 107-130. Available at: <http://doi. org/10.3726/978-3-653-01426-6>.

Götz, Maya; Hofmann, Ole; Brosius, HansBernd; Carter, Cynthia; Chan, Kara; Donals, St. H., and Zhang, H. (2008). “Gender in Children's Television Wolrdwide”. Televizion, 21, pp. 4-9.

Gündüz, Musab and Gündüz, Ammar (2019). Hizlı Ayaklar [Quick Feet]. Available at: <http://www.minikago.com.tr/programlar/ hizliayaklar>. Accessed 15 August 2020.
Gündüz, Musab and Gündüz, Ammar (2016). İstanbul Muhafizları [Istanbul Guards]. Available at: <http://www.neher.com.tr/ portfolio/istanbul-muhafizlari>. Accessed 15 August 2020.

Hall, Stuart (2017). "Temsil İşi” [Representation]. In: Hall, Stuart (ed.). Temsil Kültürel Temsiller ve Anlamlandirma Uygulamalar [Representation: Cultural Representations and Signifying Practices]. (İ. Dündar, Trans.). İstanbul: Pinhan Publications, pp. 21-98.

Jaggi, Ruchi (2015). "Deconstructing Gender in Cartoon Programming on Children's Television Channels in India a Textual Analysis". IMS Manthan, 10(1), pp. 123-130.

Kaygısız, Ozan (2017). Neşeli Dünyam [My Merry World]. Available at <http://www. minikacocuk.com.tr/programlar/neselidunyam>. Accessed 15 August 2020.

Lemish, Dafna (2010). Screening Gender on Children's Television: The Views of Producers Around the World. New York: Routledge.

-. (2014). "Boys are... Girls are... How Children's Media and Merchandizing Construct Gender". In: Carter, Cynthia; Steiner, Linda, and McLaughlin, Lisa (ed.). The Routledge Companion to Media and Gender. New York: Routledge, pp. 179-189.

Livingstone, Sonia (2007). "Do the Media Harm Children? Reflections on New Approaches to an Old Problem". Journal of Children and Media, 1(1), pp. 5-14. DOI: $<10.1080 / 17482790601005009>$.

Martin, Ashley and Philips, Katherine (2017). “What 'Blindness' to Gender Differences Helps Women See and Do: Implications for Confidence, Agency, and Action in Male-dominated environments". Organizational Behavior and Human Decision Processes, 142, pp. 28-44. DOI: $<10.1016 /$ j.obhdp.2017.07.004>.

McKee, Alan (2003). Textual Analysis: A Beginner's Guide. London: Sage.

Messenger-Davies, Marie (2008). “Children's Television". In: Creeber, Glen (ed.). The Television Genre Book. London: Palgrave Macmillan, pp. 92-101. 
Özkan, Ümit (2016). Altın Ögütler [Pearl of Wisdom]. Available at <https://www.youtube. com/watch?v=kzPUVas8tbw $>$. Accessed 28 April 2021.

Radio and Television Supreme Council (2016). Medya Hizmet Sağlayıcılar [Audio Visual Sector]. Available at: <http://www.rtuk.gov.tr/ medya-hizmet-saglayicilar-3747>. Accessed 16 August 2020.

Scantlebury, Kathryn (1995). "Challeging Gender Blindness in Preservice Secondary Science Teachers". Journal of Science Teacher Education, 6(3), pp. 134-142. DOI: <10.1007/ BF02614571>.

Şentatoğlu, Osman and Merati, Nasser (2018). "Gece" [Night]. In: N. Yazı, Alpman. Available at: <http://www.minikago.com.tr/ programlar/alpman>. Accessed 15 August 2020.

Thompson, Teresa and Scantlin, M. Rondo (2007). "Cartoons, Gender Representation". In: Arnett, Jeffrey (ed.). Encyclopedia of Children, Adolescents and the Media. California: Sage Publications, pp. 140-143.
Thompson, Teresa and Zerbinos, Eugenia (1995). "Gender Roles in Animated Cartoons: Has the Picture Changed in 20 Years?". A Sex Roles: A Journal of Research, 32(9-10), pp. 651-673. DOI: <10.100/BF01544217>.

Timisi, Nilüfer (2011). Elektronik Bakıcı [Elektronik Baby-Sitter]. İstanbul: Derin Publishing.

United Nations Educational Scientific and Cultural Organization France and Bangkok Office (2019, October 1st). Gender in education Network in Asia-Pacific (GENIA) Toolkit: Promoting Gender Equality in Education. Paris: UNESCO. Available at: <https://bangkok. unesco.org/content/gender-educationnetwork-asia-pacific-genia-toolkit-promotinggender-equality-education $>$. Accessed $30 \mathrm{Au}$ gust 2020 .

Yıldırım, Fatma and Korkmaz, Erhan (2017). Maceracı Yüzgeçler [Adventurous Fins]. Available at: <http://www.minikacocuk.com. tr/programlar/maceraci-yuzgecler $>$. Accessed 15 August 2020 